\title{
Challenges in the development and use of ecological indicators
}

\author{
Virginia H. Dale ${ }^{\mathrm{a}, *}$, Suzanne C. Beyeler ${ }^{\mathrm{b}, 1}$ \\ a Environmental Sciences Division, Oak Ridge National Laboratory, Oak Ridge, TN 37831-6036, USA \\ ${ }^{\mathrm{b}}$ Institute of Environmental Sciences, Miami University, Oxford, OH 45058, USA
}

Accepted 7 March 2001

\begin{abstract}
Ecological indicators can be used to assess the condition of the environment, to provide an early warning signal of changes in the environment, or to diagnose the cause of an environmental problem. Ideally the suite of indicators should represent key information about structure, function, and composition of the ecological system. Three concerns hamper the use of ecological indicators as a resource management tool. (1) Monitoring programs often depend on a small number of indicators and fail to consider the full complexity of the ecological system. (2) Choice of ecological indicators is confounded in management programs that have vague long-term goals and objectives. (3) Management and monitoring programs often lack scientific rigor because of their failure to use a defined protocol for identifying ecological indicators. Thus, ecological indicators need to capture the complexities of the ecosystem yet remain simple enough to be easily and routinely monitored. Ecological indicators should meet the following criteria: be easily measured, be sensitive to stresses on the system, respond to stress in a predictable manner, be anticipatory, predict changes that can be averted by management actions, be integrative, have a known response to disturbances, anthropogenic stresses, and changes over time, and have low variability in response. The challenge is to derive a manageable set of indicators that together meet these criteria. Published by Elsevier Science Ltd.
\end{abstract}

Keywords: Ecological indicators; Hierarchy; Management resources

\section{Introduction}

As habitat fragmentation, changes in ecological condition, and loss of biodiversity escalate, society turns to science for guidance on dealing with complex environmental issues. Unfortunately, there are no simple solutions to many of the environmental problems of today, but clearly a commitment to con-

\footnotetext{
* Corresponding author. Tel.: +1-423-576-8043; fax: +1-423-576-8543.

E-mail address: vhd@ornl.gov (V.H. Dale).

${ }^{1}$ Present address: The Department of Natural Resources,

University of Illinois, Champaign, IL 61820, USA.
}

servation of natural resources and to understanding the implications of resource management and stress impacts is a necessary step towards addressing these complicated issues (Noss and Cooperrider, 1994). It is also imperative that, in connection with this focus on conservation, ecologists develop sound methods for monitoring, assessing, and managing ecological integrity through the use of indicators of ecological change. Ecological integrity refers to system wholeness, including the presence of appropriate species, populations, and communities and the occurrence of ecological processes at appropriate rates and scales (Angermeier and Karr, 1994; Karr, 1991) as well as the environmental conditions that support these taxa 
and processes. Thus, the concept of ecological integrity frames the selection of system-level indicators that are useful for resource managers (Karr, 1991).

Ecological indicators have several purposes (Cairns et al., 1993). They can be used to assess the condition of the environment or to monitor trends in condition over time. They can provide an early warning signal of changes in the environment, and they can be used to diagnose the cause of an environmental problem. The purpose influences the choice of ecological indicators. However, trade-offs between desirable features, costs, and feasibility often determine the choice of indicators.

A challenge in developing and using ecological indicators is determining which of the numerous measures of ecological systems characterize the entire system yet are simple enough to be effectively and efficiently monitored and modeled. Ecological indicators quantify the magnitude of stress, degree of exposure to the stresses, or degree of ecological response to the exposure (Hunsaker and Carpenter, 1990; Suter, 1993) and are intended to provide a simple and efficient method to examine the ecological composition, structure, and function of complex ecological systems (Karr, 1981) (e.g. see Table 1). The use of ecological indicators relies on the assumption that the presence or absence of, and fluctuations in, these indicators reflect changes taking place at vari-

Table 1

Example components and indicators for ecological integrity

\begin{tabular}{|c|c|c|}
\hline Hierarchy & Processes & Suggested indicators \\
\hline Organism & $\begin{array}{l}\text { Environmental toxicity } \\
\text { Mutagenesis }\end{array}$ & $\begin{array}{l}\text { Physical deformation } \\
\text { Lesions } \\
\text { Parasite load }\end{array}$ \\
\hline Species & $\begin{array}{l}\text { Range expansion or } \\
\text { contraction } \\
\text { Extinction }\end{array}$ & $\begin{array}{l}\text { Range size } \\
\text { Number of populations }\end{array}$ \\
\hline Population & $\begin{array}{l}\text { Abundance fluctuation } \\
\text { Colonization or } \\
\text { extinction }\end{array}$ & $\begin{array}{l}\text { Age or size structure } \\
\text { Dispersal behavior }\end{array}$ \\
\hline Ecosystem & $\begin{array}{l}\text { Competitive exclusion } \\
\text { Predation or parasitism } \\
\text { Energy flow }\end{array}$ & $\begin{array}{l}\text { Species richness } \\
\text { Species evenness } \\
\text { Number of tropic levels }\end{array}$ \\
\hline Landscape & $\begin{array}{l}\text { Disturbance } \\
\text { Succession }\end{array}$ & $\begin{array}{l}\text { Fragmentation } \\
\text { Spatial distribution } \\
\quad \text { of communities } \\
\text { Persistence of habitats }\end{array}$ \\
\hline
\end{tabular}

ous levels in the ecological hierarchy, from genes to species and ultimately to entire regions (Noon et al., 1999).

The ecological hierarchy includes the functional, compositional, and structural elements that, when combined, define the ecological system and provide a means to select a suite of indicators representative of the key characteristics of the system (Fig. 1). All ecological systems have elements of composition and structure that arise through ecological processes. The characteristic conditions depend on sustaining key ecological functions which in turn, produce additional compositional and structural elements. If the linkages between underlying processes and composition and structural elements are broken, then sustainability and integrity are jeopardized and restoration may be difficult and complex.

Ideally the suite of indicators should represent key information about structure, function, and composition. The complexity of Fig. 1 only hints at the intricacy of the ecological system on which it is based. The series of nested triangles in the figure are meant to suggest that knowledge of one part of the triangle may provide information to the other aspects of the system. For example, often it is easier to measure structural features that can convey information about the composition or functioning of the system than to measure composition or function (Lindenmayer et al., 2000). Sometimes measures from one scale can provide information relevant to another scale. For example, the size of the largest patch of a habitat often restricts the species or tropic levels of animals that are able to be supported based solely on their minimal territory size (Dale et al., 1994). Even so, it is often difficult to know how large an area or how long to monitor (Dawe et al., 2000). The ecological system can be viewed as a moving target (Walters and Holling, 1990) with many system variables changing slowly and not stabilizing for a long time.

\section{Concerns and challenges}

Although few scientists deny the benefits that indicators provide to research and management efforts, three concerns hamper the use of ecological indicators as a resource management tool (Landres et al., 1988; Kelly and Harwell, 1990; Noss, 1990; 
LANDSCAPE/REGION: Spatial heterogeniety; patch size, shape and distribution; fragmentation; connectivity

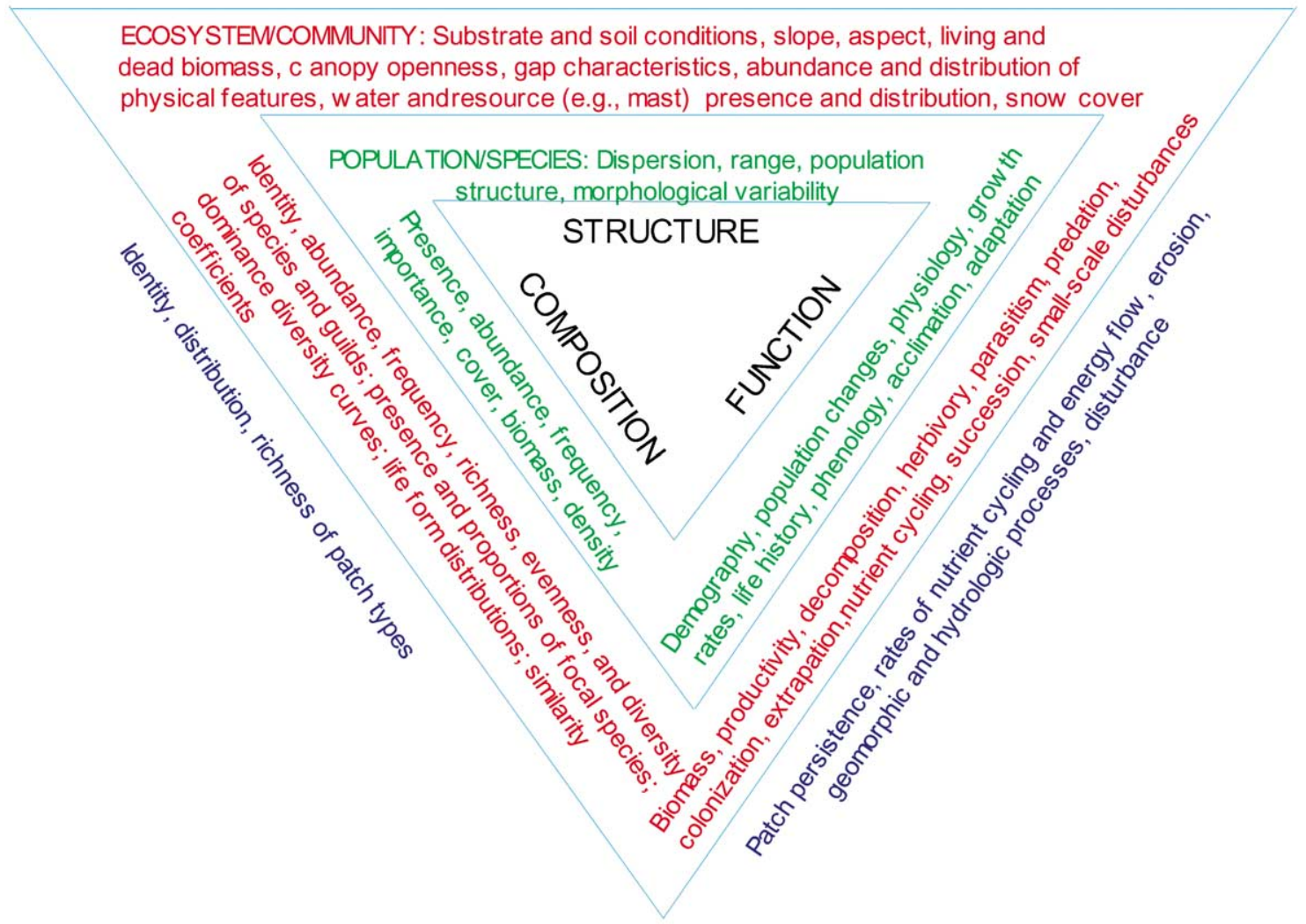

Fig. 1. The ecological hierarchy: a triangular representation of the key characteristics of composition, structure and function (derived from Franklin, 1988 and Noss, 1990).

Kremen, 1992; Cairns et al., 1993; Mills et al., 1993; Noss and Cooperrider, 1994; Gurney et al., 1995; Simberloff, 1997).

\subsection{Monitoring programs often depend on a small} number of indicators and, as a consequence, fail to consider the full complexity of the ecological system

By selecting only one or a few indicators, the focus of the ecological management program becomes narrow, and an oversimplified understanding of the spatial and temporal interactions is promoted. This simplification often leads to poorly informed management decisions. Indicators should be selected from multiple levels in the ecological hierarchy in order to effectively monitor the multiple levels of complexity within an ecological system. Thus, a key challenge is to find a mix of measures which give interpretable signals, can be used to track the ecological conditions at reasonable cost, and cover the spectrum of ecological variation.

\subsection{Choice of ecological indicators is often confounded in management programs that have vague long-term goals and objectives}

Unclear or ambivalent goals and objectives can lead to "the wrong variables being measured in the wrong place at the wrong time with poor precision or reliability" (Noss and Cooperrider, 1994). Primary goals and objectives should be determined early in the process in order to focus monitoring on current and future management issues. Ecological indicators can 
Table 2

Criteria for ecological indicators

Are easily measured

Are sensitive to stresses on system

Respond to stress in a predictable manner

Are anticipatory: signify an impending change in the ecological system

Predict changes that can be averted by management actions

Are integrative: the full suite of indicators provides a measure of coverage of the key gradients across the ecological systems (e.g. soils, vegetation types, temperature, etc.)

Have a known response to natural disturbances, anthropogenic stresses, and changes over time

Have low variability in response

then be selected to measure system characteristics that most closely relate to those management concerns. However, society typically has selected resource management goals concerned solely with short-term profit (e.g. maximum crop yield in agricultural systems or maximum timber production in forests). These goals may jeopardize the long-term maintenance of healthy ecological systems. Management goals, and thus indicator selection should be tied to an understanding of both the short-term and long-term consequences of resource management decisions.

\subsection{Management and monitoring programs often} lack scientific rigor because of their failure to use a defined protocol for identifying ecological indicators

Lack of robust procedures for selecting ecological indicators makes it difficult to validate the information provided by those indicators. Until standard methods are established for selecting and using indicators, interpretation of their change through space and time remains speculative (Noss, 1999). The creation and use of standard procedures for the selection of ecological indicators allow repeatability, avoid bias, and impose discipline upon the selection process, ensuring that the selection of ecological indicators encompasses management concerns (Slocombe, 1998; Belnap, 1998).

\section{Criteria for selecting ecological indicators}

Selection of effective indicators is key to the overall success of any monitoring program. In general, ecological indicators need to capture the complexities of the ecosystem yet remain simple enough to be easily and routinely monitored. In order to define ecological indicators, however, it is first necessary to set forth criteria used to select potential ecological indicators. Building upon discussions by Landres et al. (1988), Kelly and Harwell (1990), Cairns et al. (1993), and Lorenz et al. (1999), we suggest that ecological indicators should meet the following criteria (Table 2):

- Be easily measured: The indicator should be straightforward and relatively inexpensive to measure. The metric needs to be easy to understand, simple to apply, and provide information to managers and policymakers that is relevant, scientifically sound, easily documented, and cost-effective (Stork et al., 1997; Lorenz et al., 1999). Historically, canaries were carried into mines to warn workers of the presence of methane and other gases that can lead to an explosion. The death of a canary is an easily observed, if unfortunate (for the canary), result of the presence of volatile gases. When a bird succumbed to toxic gas, it was an indication to the miners were in imminent danger.

- Be sensitive to stresses on the system: The ideal ecological indicator is responsive to stresses placed on the system by human actions while also having limited and documented sensitivity to natural variation (Karr, 1991). While some indicators may respond to all dramatic changes in the system, the most useful indicator is one that displays high sensitivity to a particular and, perhaps, subtle stress, thereby serving as an early indicator of reduced system integrity. For example, the gopher tortoise (Gopherus polyphemus) is highly sensitive to soil disturbances, and their absence in otherwise suitable sites suggests past physical disturbances. (This 
Table 3

An example of an ecological indicator

An example of an ecological indicator is the presence of the cyanobacteria Oscillatoria rubescens in lakes that are on the verge of extreme eutrophication. The role of this cyanobacteria as an indicator was first identified in Lake Washington (Edmondson and Lehman, 1981; Edmondson, 1991). In the first half of the 20th century, metropolitan Seattle discharged treated sewage high in phosphorus content into Lake Washington. By 1955, effluent contributed more than 50\% of the total phosphorus input into the lake. Increased nutrient levels altered lake productivity and resulted in massive blooms of cyanobacteria that negatively affected fish populations and greatly reduced water clarity. Public attention was called to the problem, and the resulting reversal of this eutrophication process occurred when sewage was diverted from the lake and into Puget Sound. The resulting drop in nutrient additions eliminated algal blooms and increased water clarity. Now, $O$. rubescens is used as an indicator of impending eutrophication worldwide. It satisfies three elements of an ecological indicator in that it is easily measured, it signifies an impending change in the ecosystem, and both the potential ecosystem change and the high level of the indicator can be averted by management action. (Unfortunately, Puget Sound still suffered even after advances were made in the sewage treatment system).

interpretation of the tortoise's absence in sand hills areas can be made only when there are no other pressures on the tortoise, such as harvesting tortoise for food or gassing burrows to collect snakes.)

- Respond to stress in a predictable manner: The indicator response should be unambiguous and predictable even if the indicator responds to the stress by a gradual change (such as the increase in density of the cyanobacteria Oscillatoria rubescens in polluted lakes). Ideally, there is some threshold response level at which the observable response occurs before the level of concern (Table 3).

- Be anticipatory, i.e. signify an impending change in key characteristics of the ecological system: Change in the indicator should be measurable before substantial change in ecological system integrity occurs. For the canaries in the coal mine example, the birds died at levels of toxic gases not quite sufficient to create an explosion or be toxic to humans.

- Predict changes that can be averted by management actions: The value of the indicator depends on its relationship to possible changes in management actions. For example, the presence of young longleaf pine (Pinus palustris) serves as a measure of the recurrence of fire at Eglin Air Force Base (AFB) on the Florida panhandle (McCay, 2000). With fire suppression, the normally restricted distribution of sand pine ( $P$. clausa) expanded from 2400 ha to over 24,000 ha, and young longleaf pine became rare. It has only been through the reintroduction of a regular fire regime at Eglin AFB that the historically dominant species, longleaf pine, has been reestablished. Today, the presence of young longleaf pine, which survive light fire, is a result of the artificially-induced 2 to 3-year fire regimes that occur not only at Eglin AFB but also at other managed areas in the southeastern United States. In contrast, effects of large, infrequent disturbances often serve as a counter example of changes that cannot be averted by management actions (Dale et al., 1998). Ecological effects of volcanoes, large climate-induced fires, and hurricanes cannot be predicted by ecological indicators nor deterred.

- Are integrative: the full suite of indicators provides a measure of coverage of the key gradients across the ecological systems (e.g. gradients across soils, vegetation types, temperature, space, time, etc.): The full suite of indicators for a site should integrate across key environmental gradients. For example, no single indicator is applicable across all spatial scales of concern. Brooks et al. (1998) developed a suite of indicators for forested riparian ecosystems of Louisiana that behave predictably across scales and can be aggregated to provide an assessment of the entire system. In a like manner, the ability of the suite of indicators to embody the diversity in soils, topography, disturbance regimes, and other environmental gradients at a site should be considered.

- Have a known response to disturbances, anthropogenic stresses, and changes over time: The indicator should have a well-documented reaction to both natural disturbance and to anthropogenic stresses in the system. This criterion would pertain to conditions that have been extensively studied and have a clearly established pattern of response. Focal species are often the only types of species that 
Table 4

Categories of focal species

Indicator species are species whose status is indicative of the status of a larger functional group of species, reflects the status of key habitats, or acts as an early warning to the action of an anticipated stressor (e.g. white-tailed deer (Odocoileus virginianus) populations that signify the availability of forest-grassland margins).

Keystone species have much greater effects on one or more ecological processes than would be predicted from their abundance or biomass alone (Power et al., 1996) (e.g. the red-cockaded woodpecker (Picoides borealis) creates cavities in living trees that provide shelter for 23 other species (Dennis, 1971)).

Ecological engineers alter the habitat to their own needs and by doing so affect the fates and opportunities of other species (e.g. Jones et al., 1994; Naiman and Rogers, 1997) (such as the gopher tortoise (G. polyphemus) that digs burrows used by many other species or the beaver (Castor canadensis) whose dams create wetlands).

Umbrella species have either large area requirements or use multiple habitats that encompass the habitat requirements of many other species (e.g. the northern spotted owl (Strix occidentalis caurina) that occupy old growth forest in the Pacific Northwest).

Link species play critical roles in the transfer of matter and energy across tropic levels or provide a critical link for energy transfer within complex food webs. For example, prairie dogs (Cynomys spp.) in grassland ecosystems convert primary plant productivity into animal biomass. Prairie dog biomass, in turn, supports a diverse predator community.

Special interest species include threatened and endangered species, game species, charismatic species and those that are vulnerable due to their rarity.

have a large enough foundation of information to indicate long-term trends and responses to change (Table 4). Landscape structure can also respond to human disturbances versus natural disturbances in a predictable manner (Krummel et al., 1987). Thus, landscape metrics can serve as useful indicators of change (O'Neill et al., 1988; Dale and Pearson, 1997; Gustafson, 1998; Klemas, 2001).

- Have low variability in response: Indicators that have a small range in response to particular stresses allow for changes in the response value to be better distinguished from background variability. As a counter example, seabirds were a poor indicator of the ecological cost of the 1989 Exxon Valdez oil spill and of the benefit of subsequent steam cleaning. More than 30,000 oiled bird carcasses were retrieved following the spill, but because of the high variability inherent in seabird populations, the population dynamics of birds in the spill areas are difficult to distinguish from the population dynamics of birds at nonspill sites (Wiens, 1996).

A challenge is to derive a manageable set of indicators that together meet these criteria.

\section{Conclusions}

Ecological indicators are used to monitor, assess, and manage natural resources. A difficulty in selecting appropriate indicators is dealing with the complexity of ecological systems. Thus, it is necessary to use a suite of indicators representative of the structure, function, and composition of ecological systems. The need to communicate the scientific concepts of ecological indicators to non-scientists is being tackled by teams of environmental scientists working with social scientists (e.g. Schiller et al., 2001). Yet, integrating ecological indicators with social and economic goals for resource management remains a big challenge.

\section{Acknowledgements}

Discussion with Barry Noon were helpful in developing some of these ideas. Reviews of an earlier draft of the paper by Tom Ashwood, Lisa Olsen, Linda Mann, Pat Mulholland and anonymous reviewer were quite helpful. The manuscript was edited by Linda O'Hara. The project was funded by contracts from the Strategic Environmental Research and Development Program (SERDP), Ecosystem Management Program (SEMP) and the US Air Force to Oak Ridge National Laboratory (ORNL). ORNL is managed by UT-Battelle, LLC for the US Department of Energy under contract DE-AC05-00OR22725. This is Environmental Sciences Division Publication No. 4946. 


\section{References}

Angermeier, P.L., Karr, J.R., 1994. Biological integrity versus biological diversity as policy directives: protecting biotic resources. BioScience 44, 690-697.

Belnap, J., 1998. Environmental auditing: choosing indicators of natural resource condition: a case study in Arches National Park, UT, USA. Environ. Manage. 22, 635-642.

Brooks, R.B., O'Connell, T.J., Wardrop, D.H., Jackson, L.E., 1998. Towards a regional index of biological integrity: the example of the forested riparian ecosystem. Environ. Monit. Assess. 51, 131-143.

Cairns, J., McCormick, P.V., Niederlehner, B.R., 1993. A proposed framework for developing indicators of ecosystem health. Hydrobiologia 236, 1-44.

Dale, V.H., Pearson, S.M., 1997. Quantifying habitat fragmentation due to land-use change in Amazonia. In: Laurance, W.F., Bierregaard, R.O. (Eds.), Tropical Forest Remnants: Ecology, Management and Conservation of Fragmented Communities. The University of Chicago Press, Chicago, IL, pp. 400-410.

Dale, V.H., Offerman, H., Pearson, S., O'Neill, R.V., 1994. Effects of forest fragmentation on neotropical fauna. Conservation Biol. 8, 1027-1036.

Dale, V.H., Lugo, A., MacMahon, J., Pickett, S., 1998. Ecosystem management in the context of large, infrequent disturbances. Ecosystems 1, 546-557.

Dawe, N.K., Bradfield, G.E., Boyd, W.S., Trethewey, D.E.C., Zolbrod, A.N., 2000. Marsh creation in a northern Pacific estuary: is thirteen years of monitoring vegetation dynamics enough? Conservation Ecol. 4, 12. [online] URL: http://www. consecol.org/vol4/iss2/art12.

Dennis, J.V., 1971. Species using red-cockaded woodpecker holes in northeastern South Carolina. Bird-Banding 42, 79-87.

Edmondson, W.T., 1991. The Uses of Ecology: Lake Washington and Beyond. University of Washington Press, Seattle, WA.

Edmondson, W.T., Lehman, J.T., 1981. The effect of changes in the nutrient income on the condition of Lake Washington. Limnol. Oceanogr. 26, 1-29.

Franklin, J.F., 1988. Structural and temporal diversity in temperate forests. In: Wilson, E.O. (Ed.), Biodiversity. National Academy Press, Washington, DC, pp. 166-175.

Gurney, W., Ross, A., Broekhuizen, N., 1995. Coupling dynamics of systems and materials. In: Jones, C., Lawton, J. (Eds.), Linking Species and Ecosystems. Chapman \& Hall, London, pp. 176-193.

Gustafson, E.J., 1998. Quantifying landscape spatial pattern: what is the state of the art? Ecosystems 1, 143-156.

Hunsaker, C.T., Carpenter, D.E. (Eds.), 1990. Environmental Monitoring and Assessment Program: Ecological Indicators. Office of Research and Development, United States Environmental Protection Agency, Research Triangle Park, NC.

Jones, C.J., Lawton, J.H., Shachak, M., 1994. Organisms as ecosystem engineers. Oikos 69, 373-386.

Karr, J.R., 1981. Assessment of biotic integrity using fish communities. Fisheries 6, 21-27.

Karr, J.R., 1991. Biological integrity: a long neglected aspect of water resource management. Ecol. Applications 1, 66-84.
Kelly, J.R., Harwell, M.A., 1990. Indicators of ecosystem recovery. Environ. Manage. 14, 527-545.

Klemas, V.V., 2001. Remote sensing of landscape-level coastal environmental indicators. Environ. Manage. 27, 47-57.

Kremen, C., 1992. Assessing the indicator properties of species assemblages for natural areas monitoring. Ecol. Applications 2, 203-217.

Krummel, J.R., Gardner, R.H., Suhihara, G., O’Neill, R.V., 1987. Landscape patterns in a disturbed environment. Oikos 48, 321-324.

Landres, P.B., Verner, J., Thomas, J.W., 1988. Ecological uses of vertebrate indicator species: a critique. Conservation Biol. 2, 316-328.

Lindenmayer, D.B., Margules, C.R., Botkin, D.B., 2000. Indicators of biodiversity for ecological sustainable forest management. Conservation Biol. 14, 941-950.

Lorenz, C.M., Gilbert, A.J., Cofino, W.P., 1999. Indicators for transboundary river basin management. In: Pykh, Y.A., Hyatt, D.E., Lenz, R.J.M. (Eds.), Environmental Indices: System Analysis Approach. EOLSS Publishers Co. Ltd., Oxford, UK, pp. 313-328.

McCay, D.H., 2000. Effects of chronic human activities on invasion of longleaf pine forests by sand pine. Ecosystems 3, 283-292.

Mills, L.S., Soule, M.E., Doak, D.F., 1993. The keystone species concept in ecology and conservation. BioScience 43, 219-224.

Naiman, R.J., Rogers, K.H., 1997. Large animals and system-level characteristics in river corridors. BioScience 47, 521-529.

Noon, B.R., Spies, T.A., Raphael, M.G., 1999. Conceptual basis for designing an effectiveness monitoring program. In: Mulder, B.S., et al. (Eds.), The Strategy and Design of the Effectiveness Monitoring Program for the Northwest Forest Plan. US Department of Agriculture, Forest Service, Gen. Tech. Rep. PNW-GTR-437, Portland, OR, pp. 21-48.

Noss, R.F., 1990. Indicators for monitoring biodiversity: a hierarchical approach. Conservation Biol. 4, 355-364.

Noss, R.F., 1999. Assessing and monitoring forest biodiversity: a suggested framework and indicators. Forest Ecol. Manage. $115,135-146$.

Noss, R.F., Cooperrider, A.Y., 1994. Saving Natures Legacy. Island Press, Washington, DC.

O'Neill, R.V., Krummel, J.R., Gardner, R.H., Sugihara, G., Jackson, B., DeAngelis, D.L., Milne, B.T., Turner, M.G., Zygmnuht, B., Christensen, S.W., Dale, V.H., Graham, R.L., 1988. Indices of landscape pattern. Landscape Ecol. 1, 153-162.

Power, M.E., Tilman, D., Estes, J.A., Menge, B.A., Bond, W.J., Mills, L.S., Daily, G., Castilla, J.C., Lubchenco, J., Paine, R.T., 1996. Challenges in the quest for keystones. BioScience 46, 609-620.

Schiller, A., Hunsaker, C.T., Kane, M.A., Wolfe, A.K., Dale, V.H., Suter, G.W., Russell, C.S., Pion, G., Hadley, M., Konar, V.C., 2001. Communicating ecological indicators to decision-makers and the public. Conservation Ecol., 5 (1): 19 [online] URL:http://www.consecol.org/vol5/iss1/art19.

Simberloff, D., 1997. Flagships, umbrellas, and keystones: is single species management passé in the landscape era? Biol. Conservation 83, 247-257.

Slocombe, D.S., 1998. Defining goals and criteria for ecosystembased management. Environ. Manage. 22, 483-493. 
Stork, N.E., Boyle, T.J.B., Dale, V.H., Eeley, H., Finegan, B., Lawes, M., Manokaran, N., Prabhu, R., Sorberon, J., 1997. Criteria and Indicators for Assessing the Sustainability of Forest Management: Conservation of Biodiversity. Center for International Forestry Research. Working Paper No. 17, Bogor, Indonesia.
Suter, G., 1993. Ecological Risk Assessment. Lewis Publishers, Ann Arbor, MI.

Walters, C.J., Holling, C.S., 1990. Large-scale management experiments and learning by doing. Ecology 71, 2060-2068.

Wiens, J.A., 1996. Oil, seabirds, and science: the effects of the Exxon Valdez oil spill. BioScience 46, 471-497. 